\title{
COMPUTER TECHNOLOGIES FOR DETERMINING INDEX ASSESSMENT OF HARD DENTAL TISSUES DESTRUCTION
}

\author{
Yanishen I.V., German S.A., Al-Saedi Z.A. \\ Kharkiv National Medical University, Ukraine \\ https://doi.org/10.35339/ic.8.3.188-193
}

\begin{abstract}
The aim of the study was to compare the obtained data of hard dental tissues destruction indices with the corresponding indications for the choice of the method of treatment by means of mathematical analysis. Materials \& methods. 120 patients aged 20 to 55 were examined and 358 teeth hard tissue defects were identified in them. The data of indices was obtained and compared with the indications for orthopedic treatment according two indices in the same clinical situation. Results. The study showed that the indices had different meanings and different indications for treatment in the same situations. Such discrepancies in indications for treatment indicate the subjective data of one of the indices, which does not take into account the depth of destruction and the volume of the remaining natural tissue of the teeth. Comparison of these indices showed different figures in the same clinical situation, identifying corresponding incorrect indications for the choice of the design of the first investigated index, as well as more accurate data of the proposed index. Conclusion. The index assessment of hard dental tissues destruction serves as the main guideline for the dentist when choosing a method for tooth restoration, and can be calculated using photographs, scans and computer software.

Keywords: inlays, crown defect, index assessment, microprostheses, orthopedic treatment, indications for tooth restoration method, tooth destruction.
\end{abstract}

\section{Introduction}

One of the main tasks of prosthetic dentistry is to correct the choice of denture design. Dentists must choose a method of restoration of tooth destruction from the following: filling, inlay, veneer, crown, pin construction. Often dentists unreasonably expand the indications for the use of composite restorations, which in the future leads to the destruction of natural tooth tissues, and violation of the warranty period $[1,2]$.

The main criteria for choosing a method of tooth restoration are the degree of hard tissues destruction, height, area and thickness of the tooth walls, presence of pulp, direction of masticatory pressure, material of the future structure, and the method of artificial material for fixation [3-5].

It is very important to determine the extent of the defect using different methods of tooth

Corresponding Author:

Stanislav German MD, $\mathrm{PhD}$,

Assistant of the Professor, Department

of Orthopedic Dentistry,

Kharkiv National Medical University, Ukraine.

E-mail: sa.herman@knmu.edu.ua restoration (direct or indirect restoration) and the material of restoration, for predicting the service life of microprosthesis. Also, the composite structure, which is formed when restoring the integrity of the tooth, creates an inseparable synthesis of "natural tooth and filling material", "tooth-inlay", "tooth-crown", etc. [6, 7].

All-ceramic inserts made in the laboratory by injection molding or milling have been widely used recently. The volume ratio of natural and artificial tooth tissues determines the reliability for each design and also determines the indication for a particular method of tooth restoration $[8,9]$.

The development of adhesive systems in dentistry has achieved some success, in connection with which the need to completely dissect all tooth surfaces under the full crown has disappeared. The principle of biological expediency and minimal invasion during tooth preparation has gained new popularity in modern dentistry. Partial orthopedic restorations, such as half-crowns, overlays, equatorial and threequarter crowns, are increasingly used to preserve natural tooth tissues [10-12]. 
To assess the degree of hard tissues destruction of the lateral teeth, Milikevich proposed an index of occlusal surface destruction of the tooth (IOSD) in 1984 [13]. It is possible to use different methods of IOSD assessment by Milikevich, namely visual detection, by means of a graduated dental mirror, on models of jaws, by means of a transparent plate and a millimeter paper, and use of photos of a tooth. Milikevich identified the following indications for treatment:

IOSD - up to 0.4 - the defect is replaced by direct restoration;

IOSD - from 0,4 to 0,6 - the defect is restored by an inlay, onlay, and overlay;

IOSD - from 0.6 to 0.8 - restoration by artificial crowns;

IOSD - from 0.8 to 1.0 - restoration by various modifications of pin constructions.

However, the IOSD index has not been widely used, due to inaccuracies, as in the process of determining the degree of destruction and due to not taking into account the volumetric destruction [14].

The index of volumetric destruction of tooth tissues (PORTZ) proposed by Yanishen and Golik in 1997. It is calculated by the ratio of the volume of destroyed tooth tissue to the volume of crown tissue [15]. Identification of the destruction degree by the index of volumetric destruction of tooth tissues (PORTZ) is not only a diagnostic test, but also a determining factor in choosing a method of treatment (filling, tab, pin tooth and artificial crown) to prevent further destruction of the crown, tooth extraction [16].

To solve the problem of index assessment of tooth destruction, it is advisable to use an optical impression with subsequent mathematical analysis of the three-dimensional image. It is also possible to use a combination of digital and analog approaches, get prints, cast models, followed by scanning. Such technologies for making dental inlays have been used for a long time. The most well-known computer technology for making tabs is the "CEREC" method, which was developed in 1980 by Morman and Brandestini. In addition to the "CEREC" system, there are others, such as "The Duret system" (developed in 1985 in Grenoble, France). "The Minnesota system" (developed by Kekon in 1986 at the University of Minnesota, USA), "CAD/CAM" system Sopha Bioconcept" developed in 1991 [17-20].

Given all the above, the definition of indications for treatment, as well as the correct index assessment of tooth destruction is still a topical issue in dentistry.

\section{Purposes, Subjects and Methods}

2.1. Purpose of the study was to compare the obtained data of dental hard tissues destruction indices and the corresponding indications for the choice of the treatment method by means of mathematical analysis.

\subsection{Subjects \& Methods}

The study was conducted on the base of the University Dental Center of Kharkiv National Medical University. Among the examined 120 patients, 358 teeth with hard tissue defects were identified.

The obtained indicators of the index of occlusal surface destruction (IOSD) of the tooth were compared, with the proposed index, as well as the obtained indications for orthopedic treatment according to the two indices in the same clinical situation. Milikevich's IOSD index was determined by obtaining a clinical photograph or a screenshot of a digital impression from Exocad (Version 3.0 Galway), followed by image processing in "Adobe Photoshop" graphics editor. The display of the grid in the image included View Show - Grid. The image was unfolded and aligned along the edges of the grid (Ctrl-A, Ctrl-T). The areas of the cavity were marked with the letter " $\Pi$ " in those squares where the area of the destroyed tooth surface was much larger than the preserved one. Calculation of the total area of the occlusal surface, squares were taken into account, where the tooth tissue occupied more than a half of it. Then the number of these squares with destruction was divided by the total number of squares to receive the index. In our example shown in Figure 1, the total area of the occlusal surface of the tooth was 28 squares, and the area of the cavity comprised 13 squares. Thus, this tooth had IOSD $=13: 28=0.46$.

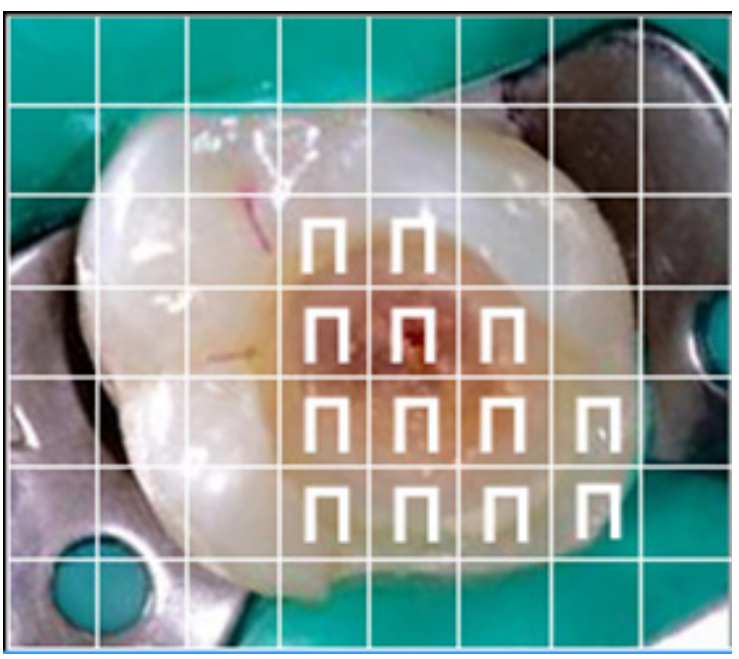

Fig. 1. An example of IOSD calculation 
To increase the accuracy of the study it is necessary to clarify some parameters used in the calculation. The shape of the tooth is far from the correct geometric. In this regard, calculations should involve determination of the maximum and minimum dimensions, followed by determination of the average value. The occlusal surface and the shape of the defect should be considered as a geometric figure - an ellipse, and the tooth as an elliptical cylinder. Given that the height of the tooth crown and the depth of the cavity in most cases do not match, we have proposed an index of volumetric destruction of the clinical crown of the tooth (IVDCC) (Fig. 2) which is calculated by the formula:

$$
\text { IVDCC }=\frac{r \max * r \min *(h \max +h \min )}{R \max * R \min *(\max +H \min )}
$$

where $r_{\max }$ - the maximum radius of the defect;

$r_{\min }$ - the minimum radius of the defect;

$\mathrm{R}_{\max }-$ maximum radius of the occlusal surface;

$\mathrm{R}_{\min }-$ minimum radius of the occlusal surface;

$\mathrm{h}_{\max }$ - maximum depth of the defect cavity;

$\mathrm{h}_{\min }$ - the minimum depth of the defect cavity;

$\mathrm{H}_{\max }^{\min }$ - the maximum height of the clinical crown of the tooth;

$\mathrm{H}_{\min }$ - the minimum height of the clinical crown of the tooth.

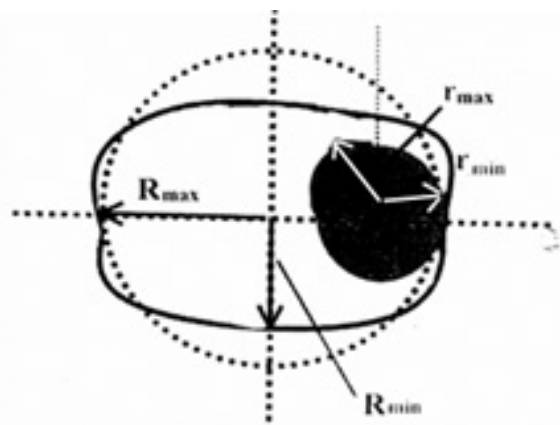

Fig. 2. A scheme of a tooth with designations for IVDCC

A differentiated choice of a method of hard dental tissues defect restoration involved determination of the following indications by IVDCC:

IVDCC degree 1 to 0.2 - the defect is replaced by direct filling;
IVDCC degree 2 from 0.2 to 0.55 - the defect is replaced by a direct filling or indirect tab (inlay, onlay, overlay);

IVDCC degree 3 from 0.55 to 0.75 - the defect is replaced by artificial crowns or overlay;

IVDCC degree 4 from 0.75 to 1.0 - the defect is replaced by various modifications of pin designs.

\section{Results \& Discussion}

Among the examined 120 patients, 358 teeth with hard tissue defects were identified. The two indices were calculated for each tooth according to the described methods. As a result, a significant difference was found in the values and indications for treatment among the compared indexes (Table).

There were 58 teeth with value $<0.4$ according to the indications of IOSD, the method of treatment of which should be a direct composite restoration, while the index IVDCC with value $<0.2$ revealed 141 cases, which should be restored by dental fillings.

Among the indications for treatment with tabs IOSD 0.4-0.59 there were 105 teeth, and 124 cases for IVDCC 0.2-0.55. Crowns according to IOSD with data of $0.6-0.8$ should be applied 133 times. As for IVDCC with value of $0.55-0.74$, there were only 65 cases. Pin structures were indicated 62 times for IOSD $0.8-1.0$, while for IVDCC $0.75-1.0$ only 28 times.

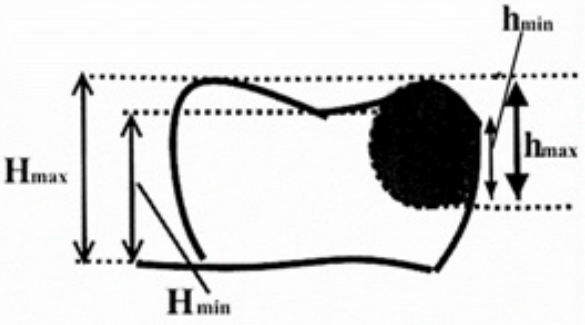

Data of the examined teeth according to the index assessment

\begin{tabular}{|l|c|c|c|c|c|c|}
\hline $\begin{array}{c}\text { Indications for treatment } \\
\text { by the method }\end{array}$ & $\begin{array}{c}\text { The value } \\
\text { of the IOSD }\end{array}$ & $\begin{array}{c}\text { Number } \\
\text { of teeth }\end{array}$ & Percentage & $\begin{array}{c}\text { The value } \\
\text { of the IVDCC }\end{array}$ & $\begin{array}{c}\text { Number } \\
\text { of teeth }\end{array}$ & Percentage \\
\hline Filling & $<0.4$ & 58 & $16.2 \%$ & $<0.2$ & 141 & $39.4 \%$ \\
\hline Inlay, onlay (tabs) & $0.4-0.59$ & 105 & $29.3 \%$ & $0.2-0.55$ & 124 & $34.6 \%$ \\
\hline Crowns, overlays & $0.6-0.79$ & 133 & $37.2 \%$ & $0.55-0.74$ & 65 & $18.1 \%$ \\
\hline Pin designs & $0.8-1.0$ & 62 & $17.3 \%$ & $0.75-1.0$ & 28 & $7.8 \%$ \\
\hline Total & \multicolumn{7}{|l|}{} & 358 & 100 & & 358 & 100 \\
\hline
\end{tabular}




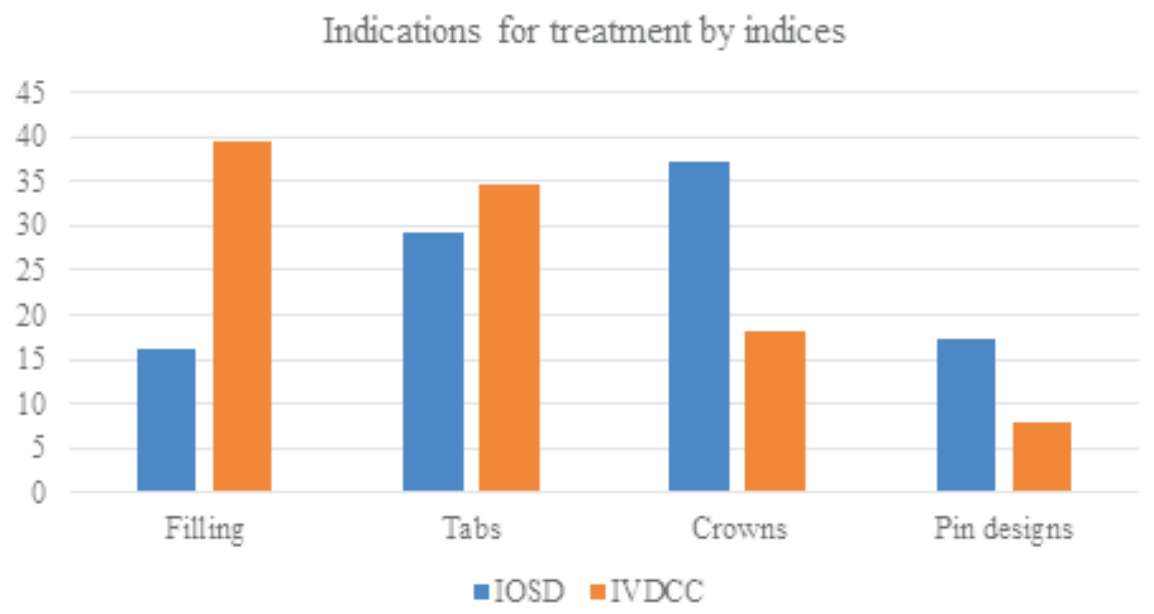

Fig. 3. Percentage of indications for treatment by indices

discrepancies of the indications indicate the subjective data of IOSD, which does not take into account the depth of destruction and the volume of the remaining natural tooth tissues.

Let us consider a clinical situation that demonstrates the inaccuracy of indications for structures according to only one occlusal surface.

Calculation of IOSD of the clinical situation of tooth 2.6, shown in Figure 4, is as follows:

IOSD $=25: 30=0.83$ which means indications for a pin design.

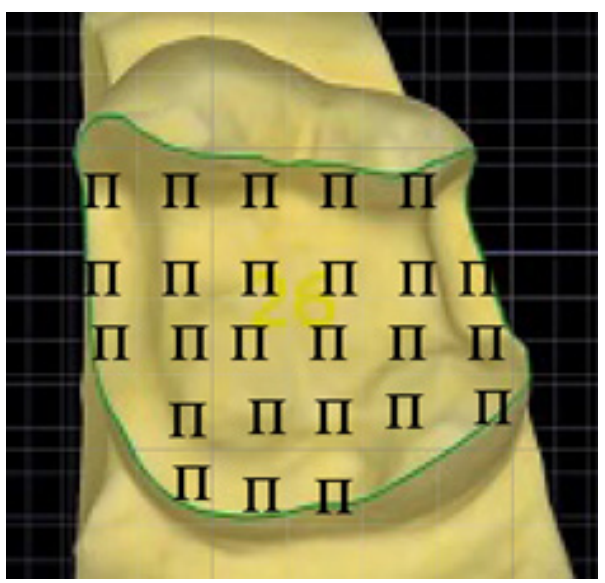

Fig. 4. Calculation of IOSD for 2.6 tooth

Let us consider the same clinical situation using the IVDCC, calculating the minimum and maximum height, diameter of the defect and the tooth (Fig. 5).

$$
\text { IVDCC }=\frac{200 * 150 *(300+150)}{240 * 140 *(460+360)} \approx 0.49
$$

As a result, two indices in the same situation have different values and indications, respectively. The IOSD recommend the pin design, and the IVDCC indicate the production of the tab. Taking into account presentation, tooth vitality, and
IVDCC data, the second option was chosen and an overlay tab was created (Figure 6).

As discussed by Jason Smithson [21], there will never be a completely black and white guide to dental treatment, and grey areas will always exist. As long as treatment is performed with care, to a high standard and with a nod to the underlying science, it will more than likely be successful.

According to the Riccardo Ammannato [22], it is necessary to take into account the principles of bioeconomics (maximum conservation of healthy tissue) and reinforcement of residual dental structure. Depending on the strength of enamel and dentin wear, the amount of caries, and the size of existing restorations, different treatment options can be applied to each tooth: direct and indirect partial restorations, or full crowns. The author believes that the index technique is a fast and conservative approach for the planning and management of a full-mouth adhesive treatment in all cases of worn dentition.

As discussed by Mykyevych [23], highquality treatment of defects in the masticatory group of teeth can be carried out by using a clinically tested choice of restorative material and method of restoration. According to him, the results of the study of wear resistance and microhardness of different dental materials are contradictory and debatable due to different methodological approaches to determining these indicators.

\section{Conclusion}

Index scores showed differences in indications for treatment. Among the 358 examined destroyed teeth, filling was required in $16.2 \%$ for IOSD and in 39.4\% for IVDCC. Tabs for IOSD were indicated in $29.3 \%$ of cases, while for 

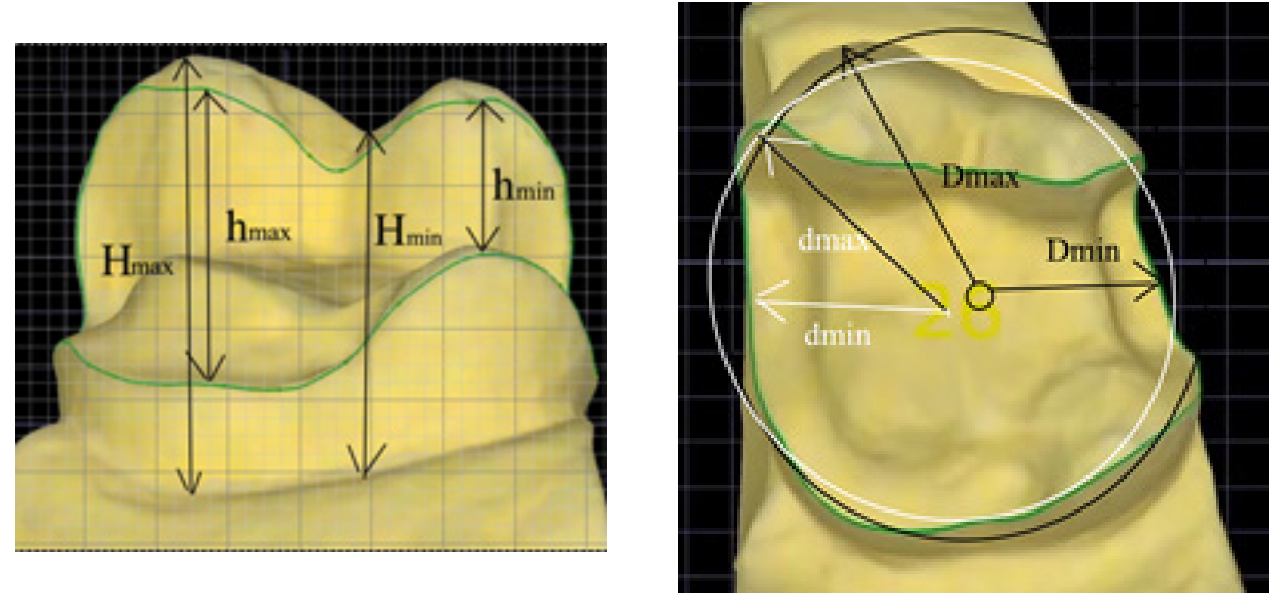

Figure 5. Calculation of IVDCC for 2.6 tooth

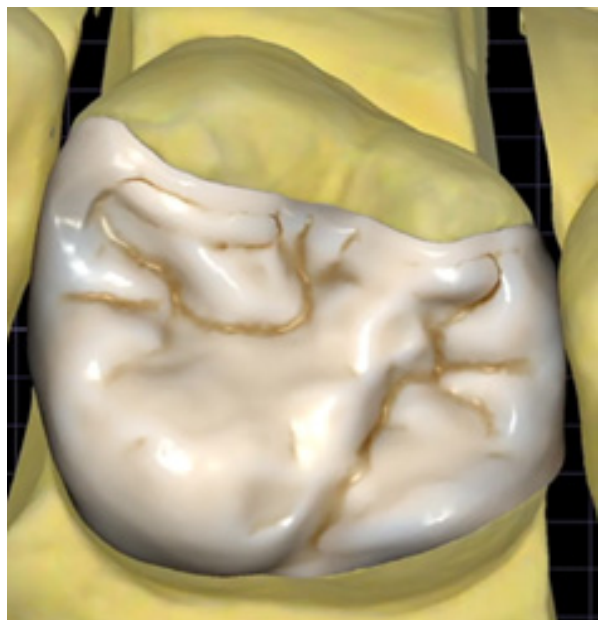

Fig. 6. Simulated overlay tab according to IVDCC indications

IVDCC in $34.6 \%$. Crowns for IOSD were needed in $37.2 \%$ of cases, and for IVDCC only in $18.1 \%$. Pin structures according to IOSD were justified in $17.3 \%$ of cases, and according to IVDCC only in $7.8 \%$. The discrepancies in the data are explained by the fact that according to Milikevich, IOSD has a significant disadvantage of taking into account only the occlusal plane.
IVDCC is a more accurate index method for choosing a method of tooth restoration, as it takes into account the destruction of the tooth in all planes. The comparison of these indices showed different figures under the same clinical conditions, indicating the corresponding incorrect indications for the choice of the design by IOSD according to Milikevich, as well as more accurate data of IVDCC. The index assessment of hard dental tissues destruction serves as the main guideline for the dentist when choosing a method for tooth restoration, and can be calculated using photographs, scans and computer software.

\section{Declarations}

\section{Statement of Ethics}

The authors have no ethical conflicts to disclosure.

\section{Consent for publication}

All authors give their consent to publication.

\section{Disclosure Statement}

Authors have nothing to disclosure.

\section{Funding Sources}

There are no external sources of funding

Data Transparency

The data can be requested from the authors.

\section{References}

1. Rozhko, M.M, Kinash, I.O. (2013). Indeksna ocinka stomatologichnogo statusu pacijentiv, jakym vygotovljaly sucil'nolyti kuksovi vkladky. Galyc'kyj likars'kyj visnyk, 20 (4), 52-54.

2. Morimoto, S, Rebello de Sampaio, F.B., Braga, M.M., Sesma, N., Ozcan, M. (2016). Survival Rate of Resin and Ceramic Inlays, Onlays, and Overlays: A Systematic Review and Meta-analysis. J Dent Res, 95(9):985-94. doi: 10.1177/0022034516652848.

3. Fron Chabouis, H., Smail Faugeron, V., Attal, J.P. (2013). Clinical efficacy of composite versus ceramic inlays and onlays: a systematic review. Dent Mater. 29(12):1209-1218.

4. McLaren, E.A., Whiteman, Y.Y. (2010). Ceramics: rationale for material selection. Compend Contin Educ Dent. 31(9):666-668, 670, 672.

5. Tribst, J.P.M., Dal Piva, A.M.O., de Melo, R.M., Borges, A.L.S., Bottino M.A., Ozcan M. (2019). Short communication: Influence of restorative material and cement on the stress distribution of posterior resin-bonded fixed dental prostheses: 3D finite element analysis. J Mech Behav Biomed Mater. 96:279284. doi: 10.1016/j.jmbbm.2019.05.004. 
6. Pavlenko O.V., Lystopad, O.P. (2014) Vybir metodyky vidnovlennja koronok pershyh moljariv (ogljad literatury). Sovrem. stomatologyja. 2: 100-103.

7. Morimoto, S, Albanesi, RB, Sesma, N, Agra, CM, Braga, MM. 2016. Main clinical outcomes of feldsphathic porcelain and glass-ceramic laminate veneers: a systematic review and meta-analysis of survival and complication rates. Int J Prosthodont. 29(1):38-49.

8. Fron Chabouis, H., Prot, C., Fonteneau, C., Nasr, K., Chabreron, O., Cazier, S., Attal, J.P. (2013). Efficacy of composite versus ceramic inlays and onlays: study protocol for the CECOIA randomized controlled trial. 14:278. doi: 10.1186/1745-6215-14-278.

9. Bul'buk, O.V. Rozhko, M.M. (2016). Optymizacija diagnostychnogo procesu pry ocinci velychyny defektiv tverdyh tkanyn zubiv pislja endodontychnogo likuvannja. Galyc. likar. visn. 23(4):7-9.

10. Yu, H.Y., Zhonghua Kou, Qiang Yi, Xue Za Zhi. (2020). Guided micro tooth preparation: from new strategies to new clinical practices.55(10):710-715. doi: 10.3760/cma.j.cn112144-20200627-00373.

11. Feitosa, S.A, Corazza, P.H., Cesar, P.F., Bottino, M.A, Valandro, L.F. (2014). Pressable feldspathic inlays in premolars: effect of cementation strategy and mechanical cycling on the adhesive bond between dentin and restoration. J Adhes Dent.16(2):147-54. doi: 10.3290/j.jad.a30555.

12. Brjanskaja, M.N., Ivanova, E.N. (2007). Sravnitel'naja harakteristika koncepcij preparirovanija karioznyh polostej v operativnoj stomatologii. Dal'nevostochnyj medicinskij zhurnal, (3), 122-126.

13. Mikljaeva, T.A. (2014). Opredelenie IROPZ s pomoshh'ju komp'juternyh tehnologij. Bjulleten' medicinskih internet-konferencij, 4 (5), 751.

14. Kl'omina V.V. (2006). Modyfikacija obchyslennja indeksu rujnuvannja okljuzijnoi' poverhni zuba (IROPZ) neprjamym metodom. Visn. stomatologii'. 1:83-88.

15. Flejsher, G.M. (2019) Indeksnaja ocenka v ortopedicheskoj stomatologii. Rukovodstvo dlja vrachej. Lipeck:Izdatel'skie reshenija.

16. Yanishen, I.V. Vidnovlennja defektiv tverdyh tkanyn zubiv vkladkamy za indeksnoju ocinkoju komp'juternyh tehnologij. Ukrai'na (Kharkiv): HNMU.

17. Papadiochou, S., Pissiotis, A.L. (2018). Marginal adaptation and CAD-CAM technology: A systematic review of restorative material and fabrication techniques. The Journal of prosthetic dentistry, 119(4), 545-551. https://doi.org/10.1016/j.prosdent.2017.07.001.

18. Duret F. (1987). La CFAO dentaire. Description generale du projet [Computer-assisted design and construction of dental prosthetics. A general description of the project]. Le Journal dentaire du Quebec, 24, 30-36.

19. Del Curto, F., Saratti, C. M., Krejci, I. (2018). CAD/CAM-based chairside restorative technique with composite resin for full-mouth adhesive rehabilitation of excessively worn dentition. The international journal of esthetic dentistry, 13(1), 50-64.

20. Mangano, F., Gandolfi, A., Luongo, G., Logozzo, S. (2017). Intraoral scanners in dentistry: a review of the current literature. BMC oral health, 17(1), 149. https://doi.org/10.1186/s12903-017-0442-x.

21. Smithson, J., Newsome, P., Reaney, D., \& Owen, S. (2011). Direct or indirect restorations. International dentistry African edition, (1), 70-80

22. Ammannato, R., Ferraris, F., \& Marchesi, G. (2015). The "index technique" in worn dentition: a new and conservative approach. The international journal of esthetic dentistry, 10(1), 68-99.

23. Mykyievych, N. (2018). Efficiency of treatment of hard tissues defects of lateral teeth with direct and indirect restorations made of composite materials: comparative clinical evaluation. Ukrainian Dental Almanac, (1), 40-46. https://doi.org/10.31718/2409-0255.1.2018.10)

Received: 30-Mar-2021

Accepted: 13-Sep-2021 